\title{
Pelatihan Membuat Banten Pejati bagi Masyarakat Desa Wisata Spiritual Suranadi Lombok Barat
}

\author{
Desak Putu Saridewi', I Made Sudarma², Ide Kade Suparta ${ }^{3}$, I Nengah Putra Kariana4 \\ 1,2,3,4 Institut Agama Hindu Negeri Gde Pudja Mataram \\ 1 desakputusaridewi@iahn-gdepudja.ac.id \\ *) Corresponding author
}

\begin{tabular}{l|l|l}
\hline Received: Mei, 2021 & Accepted: Mei, 2021 & Published: June, 2021
\end{tabular}

\begin{abstract}
Community Service Activities in the form of training to make banten pejati, aims to develop human resources as support for spiritual tourism in Suranadi village, West Lombok Regency. This activity is motivated by the absence of traders who provide banten pejati in the village, even though as a spiritual tourism area it is an attraction for tourists who want to pray. The availability of banten pejati sellers in spiritual tourism areas can also make it easy for tourists, especially those from outside the region. Based on these observations, to accommodate and develop Human Resources in Suranadi village, a training program for making banten pejati in simple packaging is needed without losing its philosophical meaning. Data collection methods used in this training program are observation, interviews, and documentation. The training begins with strengthening the understanding of the philosophy of banten pejati, then continues with demonstrations and practice in groups. The results of the evaluation showed that the participants were enthusiastic about participating in the training and showed their respective creativity in the form of the ability to make tetuasan, the design of banten pejati which was minimalist, practical, economical, and fast (in a short time). Participants are expected to be able to build the skills gained from this training in an ongoing and independent manner.
\end{abstract}

Keywords: training, banten pejati, spiritual tourism

\begin{abstract}
Abstrak
Kegiatan Pengabdian Kepada Masyarakat (PKM) dalam bentuk pelatihan membuat banten pejati ini bertujuan untuk mengembangkan Sumber Daya Manusia sebagai pendukung wisata spiritual di desa Suranadi Kabupaten Lombok Barat. Kegiatan ini dilatarbelakangi karena selama ini belum adanya pedagang-pedagang yang menyediakan banten pejati di desa tersebut padahal sebagai daerah wisata spiritual hal tersebut menjadi daya tarik bagi wisatawan yang hendak bersembahyang. Ketersediaan penjual banten pejati di daerah wisata spiritual juga dapat memberikan kemudahan bagi para wisatawan khusunya bagi yang berasal dari luar daerah. Berdasarkan pengamatan tersebut, untuk memenuhi kebutuhan yang dimaksud serta mengembangkan Sumber Daya Manusia di desa Suranadi maka sangat diperlukan program pelatihan pembuatan banten pejati dalam kemasan sederhana tanpa mengurangi makna filosofinya. Metode pengumpulan data yang digunakan
\end{abstract}


dalam program pelatihan ini adalah observasi, wawancara, dan dokumentasi. Pelatihan diawali dengan memberikan penguatan pemahaman filosofi banten pejati, kemudian dilanjutkan dengan demonstrasi dan praktek secara berkelompok. Hasil evaluasi menunjukkan bahwa para peserta antusias mengikuti pelatihan serta menunjukkan kreatifitasnya masing-masing berupa kemampuan dalam membuat tetuasan janur, rangkaian banten yang minimalis dengan konsep tetandingan praktis, ekonomis dan gelis (waktu singkat). Peserta diharapkan dapat mempertahankan keterampilan yang diperoleh dari pelatihan ini dengan terus dilatih secara mandiri.

Kata kunci: pelatihan, banten pejati, wisata spiritual

\section{PENDAHULUAN}

Kawasan Wisata Pura Suranadi merupakan daerah yang memiliki potensi sebagai daya tarik wisata spiritual. Karakteristik pura yang unik dengan memiliki lima pancoran air suci bersumber dari gunung Rinjani, kerap kali masyarakat menyebut Pura ini dengan nama Pura Panca Tirta. Kelima pancoran tersebut dipercaya oleh masyarakat sebagai media untuk menyembuhkan berbagai penyakit (ngentas male dalam bahasa sasak). Daya tarik Pura Suranadi telah menjadi ikon wisata yang dikenal oleh masyarakat Indonesia. Desa Wisata Suranadi telah ditetapkan sebagai Taman Wisata Alam Suranadi. Udara yang sejuk, alam yang indah, wisata kuliner sate bulayak yang lezat, dan tempat wisata spiritual yang unik menjadi daya tarik wisatawan untuk berkunjung.

Berdasarkan observasi lapangan dan hasil wawancara dengan tokoh masyarakat Yuliana Densi Sahalesy yang merupakan keterwakilan perempuan di Badan Permusyawaratan Desa (BPD) Desa Suranadi menunjukkan bahwa di balik keindahan alam dan keunikan pura Suranadi sebagai desa wisata spiritual, memiliki berbagai persoalan yang mengancam mundurnya perkembangan pariwisata di desa tersebut karena kurangnya pengembangan sumber daya manusia (SDM), kurangnya promosi, serta budaya penduduk lokal yang masih belum membuka diri secara utuh untuk pengembangan pariwisata budaya. Berdasarkan hasil kajian referensi dalam jurnal bahwa rendahnya partisipasi masyarakat dalam mengembangkan desa wisata akan berpengaruh pada lambatnya perkembangan wisata daerah (Dinar, 2019). Sumber daya manusia yang masih belum membuka wawasan tentang dunia pariwisata, mengakibatkan lambatnya perkembangan wisata dan income masyarakat sekitarnya.

Menurut Sukmadewi (2019) bahwa kawasan desa wisata Suranadi secara keseluruhan belum dikelola secara profesional dan optimal sehingga manfaat ekonomi belum sepenuhnya dirasakan oleh masyarakat setempat. Prinsipnya bahwa salah satu komponen penting pendukung pariwisata dalam perencanaan adalah tersedianya sumber daya manusia dalam bidang pariwisata. Senada dengan Suardana (2013), pengembangan destinasi wisata membutuhkan perencanaan yang baik dan tepat. Teknik pengembangan yang dimaksud adalah adanya aspek-aspek penunjang seperti infrakstruktur, daya tahan akan dampak pariwisata, resistensi penduduk lokal, dan lainnya. Bertolak dari pentingnya sumber daya manusia dalam pembangunan desa wisata agar masyarakat lokal dapat menerima manfaat dari pengembangan desa wisata spiritual maka peningkatan kapasitas masyarakat lokal penting untuk ditindaklanjuti.

Berdasarkan hasil observasi di lapangan menunjukkan belum banyak tersedianya pedagang yang menjual sarana upakara di sekitar pura Suranadi, terlebih lagi kemasan banten pejati yang ekonomis, praktis, dan sesuai filosofinya. Persoalan ini memberikan inpirasi untuk merubah paradigma masyarakat setempat untuk trampil dalam membuat sarana upakara yang praktis dan ekonomis guna mendukung daerah kawasan wisata spiritual. Ketertarikan ini juga didasari atas permintaan dari wisatawan yang berasal dari 
luar daerah untuk memfasilitasi banten pejati dengan kemasan yang praktis. Kesederhanaan dan kepraktisan sarana upacara tidak menjadi ukuran ketidaksempurnaannya suatu yadnya yang dilaksanakan, begitu juga sarana upacara atau banten yang megah tidak menjamin suatu yadnya dikatakan sempurna. Hal yang perlu diperhatikan dalam membuat banten adalah kelengkapan unsur-unsurnya serta makna filosofinya. Terlebih lagi yang paling penting adalah rasa ketulusikhlasan dalam mempersembahkan banten tersebut. Konsep ini sangat jelas diterangkan secara implisit di dalam Pustaka Suci Bhagavad Gïtā IX.26 sebagai berikut :

\author{
patram pușpaṁ phalaṁ toyam \\ yo me bhaktyā prayacchati \\ tad aham bhaktyupahrtam \\ aśnāmi prayatātmanạ̣
}

Artinya:

Siapapun yang mempersembahkan daun, bunga, buah, dan air kepada-KU dengan bhakti sepenuh hati, persembahan dari hati yang suci murni itulah yang akan Aku terima (Mantra, 2018)

Śloka Bhagavad Gïtā tersebut menegaskan bahwa rasa tulus ikhlas yang mengantarkan kesempurnaan dari suatu persembahan yang dilaksanakan. Walaupun caranya sederhana hanya dengan persembahan daun, bunga, buah, dan air saja tetapi memahami makna filosofi dan tujuannya, maka itulah yang dinyatakan sebagai yadnya yang berkualitas. Konsep-konsep seperti ini perlu ditumbuhkembangkan kepada semua orang sehingga dapat menjalankan ajaran agama Hindu dengan benar, tepat, dan berkualitas tanpa berorientasi pada kuantitas. Maka dari itu, sangat perlu memberikan pemahaman kepada masyarakat melalui pelatihan-pelatihan upakara yang berbasis teori dan praktek langsung. Perlu juga menjadi pemikiran bersama, bahwa pelatihan-pelatihan yang dilaksanakan juga perlu mempertimbangkan aspek ekonomis dan produktivitas sehingga memiliki nilai tambah bagi masyarakat di era global ini. Dal hal ini, pelatihan upakara yang dilaksanakan memperhatikan prinsip keseimbangan yaitu seimbang antara spiritual, religius, dan kehidupan duniawi.

Sebagai daerah pariwisata yang mengandalkan keberadaan Pura sebagai tujuan utama sangatlah perlu memperoleh perhatian yang serius dari berbagai pihak. Ketersediaan sarana dan prasarana pendukung menjadi kebutuhan yang sangat penting dalam pengembangan pariwisata tersebut. Dukungan dari seluruh elemen masyarakat sekecil apapun akan sangat bermanfaat bagi kemajuan daerah. Dan tentu saja akan memberikan manfaat yang sangat besar bagi peningkatan kesejahteraan masyarakat di sekitarnya. Secara umum Suranadi telah menjadi tujuan pariwisata utama di Pulau Lombok. Wisatawan yang datang ke daerah Suranadi tertarik karena keunikan yang menjadi ciri khasnya. Adanya sumber mata air alami yang dipercaya berasal dari Gunung Rinjani mengundang para wisatawan untuk datang berkunjung. Demikian pula dengan keberadaan Pura Suranadi menjadi tujuan wisata spiritual yang utama. Namun demikian sarana pendukung dirasakan masih kurang. Wisatawan yang berasal dari luar daerah Lombok sering mengalami kesulitan untuk memperoleh sarana upakara yang sederhana, praktis, ringkas dengan harga bersaing, tanpa mengurangi rasa keikhlasan untuk beryadnya. Dengan sarana upakara yang ada di Lombok pada umumnya, dirasakan masih cukup mahal dari segi harga. Sebagai salah satu contoh adalah banten pejati yang menjadi sarana upakara dalam persembahyangan.

Kebutuhan sarana upakara untuk memenuhi kebutuhan wisatawan dalam rangka wisata religi di Pura Suranadi perlu didukung oleh semua pihak. Keterlibatan masyarakat 
sekitar sebagai masyarakat pendukung perlu diberdayakan. Dalam hal ini masyarakat sekitar adalah penyangga utama keberadaan Pura Suranadi sebagai daerah wisata spiritual. Keterbatasan ketersediaan sarana upakara yang dibutuhkan oleh wisatawan menjadi sebuah potensi ekonomi yang menguntungkan bagi masyarakat. Minimal wisatawan yang berkunjung dengan tujuan wisata spiritual dapat dengan mudah memperoleh sarana upakara yang dibutuhkan dengan cepat, sederhana dan praktis tanpa mengurangi esensi dan makna dari sarana upakara tersebut dengan harga yang cukup murah. Pengembangan potensi usaha sarana upakara ini di Desa Suranadi nampaknya sangat baik. Dengan wilayah geografis yang masih alami, terdiri dari persawahan dan perkebunan, sangat mudah untuk memperoleh bahan-bahan yang dibutuhkan untuk pembuatan sarana upakara tersebut. Pengembangan dapat dilakukan dengan berdasarkan pada Konsep Tri Hita Karana. Konsep ini mengedepankan keseimbangan antara parahyangan (Tuhan), pawongan (Manusia) dan palemahan (Lingkungan).

Konsep tersebut merupakan satu kesatuan utuh yang saling berkaitan. Keberadaan Pura Suranadi sebagai parahyangan memenuhi kebutuhan manusia secara spiritual dalam hubungannya dengan Tuhan. Secara spiritual manusia berhubungan dengan orang lain dalam lingkup pawongan. Setiap orang akan membutuhkan orang lain untuk memenuhi kebutuhan yang tidak bisa dipenuhinya secara mandiri. Interaksi manusia tersebut terjadi dalam lingkungan yang ada, dengan harapan setiap individu merasa nyaman dengan lingkungan tersebut maupun dalam kelompoknya. Bertolak dari konsep tersebut, maka pengembangan ekonomi di Pura Suranadi menjadi sebuah potensi yang sangat besar untuk dilaksanakan. Pengembangan dapat dimulai dari hal yang sederhana seperti misalnya menyiapkan ketersediaan sarana upakara yang dibutuhkan oleh wisatawan atau bahkan masyarakat setempat yang membutuhkan. Mengacu pada permasalahan yang terjadi diupayakan sebuah pelatihan yang diikuti oleh ibu-ibu anggota masyarakat di Desa Suranadi untuk dapat membuat banten pejati secara sederhana. Banten ini nantinya akan bermanfaat untuk memenuhi permintaan pasar terutama wisatawan dari luar daerah yang berkunjung ke Suranadi.

\section{METODE PELAKSANAAN KEGIATAN}

Pelatihan membuat banten pejati ini dilaksanakan dengan tiga metode yaitu sosialisasi, pelatihan, dan diskusi (dharmatula). Tujuan metode sosialisasi adalah untuk memberikan pemahaman dan wawasan tentang pembuatan sarana upakara yadnya banten pejati di desa Suranadi. Sosialisasi ini juga memberikan gambaran mengenai potensi wisata spiritual dan kendala penyiapan sarana upakara terutama banten pejati yang sederhana di sekitar pura Suranadi. Sosialisasi dilaksanakan dengan memberikan penguatan materi tentang esensi banten pejati, tinjauan ekonomi tentang berupacara yang paraktis dan ekonomis untuk mengakomodasi para pencinta wisata spiritual. Bentuk lain dari kegiatan sosialisasi ini yaitu dengan memasang spanduk kegiatan di wantilan pura Suranadi dengan maksud agar masyarakat dapat mengetahui keberadaan kegiatan.

Metode pelatihan dilaksanakan dalam bentuk sharing pelatihan banten pejati. Adapun tujuan pelatihan yaitu untuk memberikan pengetahuan/wawasan tentang banten pejati sederhana yang harus dipersiapkan untuk orang-orang yang berwisata spiritual ke Pura Suranadi dan sekitarnya. Penyiapan banten ini ditujukan bagi masyarakat yang datang dari luar daerah. Banyaknya permintaan wistawan umat Hindu dari luar daerah, menuntut masyarakat sekitar Pura Suranadi untuk memanfaatkan peluang tersebut sehingga dapat mengakomodasinya.

Metode Diskusi (dharmatula) bertujuan untuk mengidentifikasi hasil pelatihan yang telah dilaksanakan agar peran serta masyarakat sekitar dapat mengembangkan potensi daerahnya. Pihak yang terlibat dalam pelatihan adalah para akademis dari IAHN Gde Pudja Mataram, perwakilan pemuka masyarakat, pedagang banten, pedagang canang, 
dan generasi muda Hindu. Secara keseluruhan pelaksanan pelatihan ini bertujuan untuk meningkatkan keterampilan masyarakat setempat agar memiliki kesiapan dalam menyediakan sarana upakara yang praktis, ekonomis dan gelis (cepat). Keterampilan ini diharapkan dapat meningkatkan peran serta masyarakat setempat dalam memperoleh manfaat dari keberadaan potensi daerah wisata spiritual. Senada dengan Suprastayasa (2019) dinyatakan penting dilakukan dengan praktek sebanyak mungkin untuk mengasah keterampilan.

\subsection{Teknik Pelaksanaan Kegiatan}

Teknik pengumpulan data yang digunakan dalam penulisan artikel jurnal Pengabdian Kepada Masyarakat (PKM) ini diawali dengan observasi lapangan dan wawancara dengan tokoh masyarakat, generasi muda, sarati banten. Peran keempat penulis adalah sebagai narasumber di bidang masing-masing. Penulisan jurnal ini ditinjau dari segi filsafat yadnya, tinjauan ekonomi, penguatan kepada masyarakat dalam berupakara sehingga kegiatan yadnya yang dilaksanakan sesuai kemampuan. Wawancara dilaksanakan sebelum dan sesudah berlangsunnya kegiatan pelatihan dengan sarati banten ( $\mathrm{Ni}$ Made Ayu Kerti), bahwa pelatihan banten pejati dengan kemasan yang diajarkan, sangat dibutuhkan untuk membantu mengakomodasi seluruh lapisan masyarakat agar dapat ber-yadnya sesuai dengan kemampuan masing-masing dan tanpa merubah maknanya.

Kegiatan pelatihan ini berlokasi di Wantilan Pura Pabersihan Suranadi, Kabupaten Lombok Barat, Provinsi Nusa Tenggara Barat. Mengacu pada buku Himpunan Tetandingan Upakara Yadnya (Sudarsana, 2010), dipaparkan peralatan dan bahan yang digunakan sebagai berikut.

1) Peralatan : : Besek, Pisau, Semat

2) Bahan Jejahitan : Daun Kelapa Hijau (slepan), Daun kelapa Muda (busung)

3) Bahan Daksina yang terdiri dari beras, pangi, telur itik, kemiri, gantusan, uang kepeng, sirih pamor, buah pinang, peselan (terdiri dari daun manggis, durian, salak, rambutan, dan ceroring)

4) Bahan banten : daun dadap, ketupat, jajan, pisang dan buah-buahan lainnya, minyak, kapas, benang, serbuk cendana, kacang, serundeng, ikan teri, telur asin, nasi dan tebu

Pelaksanaan kegiatan pelatihan atau praktek membuat banten pejati dilaksanakan dengan metode sebagai berikut:

1) Presentasi (Dharmawacana)

Presentasi materi pelatihan dipaparkan oleh 3 orang narasumber dengan tema masing masing yakni (1) Tinjauan Filosofi Banten menurut kitab Suci Weda, (2) Penguatan Pembuatan banten secara logis, praktis serta memiliki nilai reliomagis dan, (3) Penguatan Pembuatan banten ditinjau dari kajian ekonomi, budaya serta potensi daerah. Disamping penguatan secara spiritual setiap peserta juga mendapatkan materi pelatihan (hardcopy), dijelaskan tujuan pelatihan, kelengkapan dan bahan yang digunakan untuk membuat kemasan banten yang praktis dan sederhana

2) Praktek dan Demonstrasi

Instruktur terdiri dari 1 orang sebagai pemandu kegiatan dalam membuat banten pejati. Instruktur memaparkan secara rinci cara membuat bagian-bagian dari banten pejati. Pelatihan dilaksanakan secara berkelompok. Jumlah peserta hanya 9 (sembilan) orang dibagi menjadi 3 (tiga) kelompok. Pembatasan jumlah peserta harus dilaksanakan serta tetap mengikuti protokol kesehatan di masa pandemic covid-19. Setelah mendapat penjelasan tentang prosedur pembuatan, kemudian peserta diarahkan untuk langsung membuat tetuasan sesuai kemampuan masing-masing dengan tujuan agar memunculkan kreativitas peserta pelatihan. 


\section{HASIL DAN PEMBAHASAN}

\subsection{Pelaksanaan Kegiatan}

Pelatihan pembuatan pejati ini diawali dengan observasi tempat pelaksanaan serta melakukan koordinasi bersama kelompok PKM yang kemudian ditindaklanjuti ke lokasi Pura Suranadi untuk penjajakan tempat pelaksanan dan permohonan ijin dengan pihak terkait. Terlebih dalulu telah dilaksanakan analisis kebutuhan sebelum pelatihan dilaksanakan. Atas dasar analisis kebutuhan tersebut dilaksanakan rapat koodinasi dengan anggota PKM yang membahas tentang tema kegiatan, tempat pelaksanaan, jumlah peserta, anggaran biaya (mandiri), penentuan materi pendukung tinjauan filsafat yadnya, tinjauan ekonomi dan penguatan kepada masyarakat tentang tujuan pelatihan. Penentuan jadwal kegiatan dikoordinasikan dengan pihak terkait dan jumlah peserta ditentukan terbatas agar tidak melanggar protokol kesehatan di masa pandemic covid-19

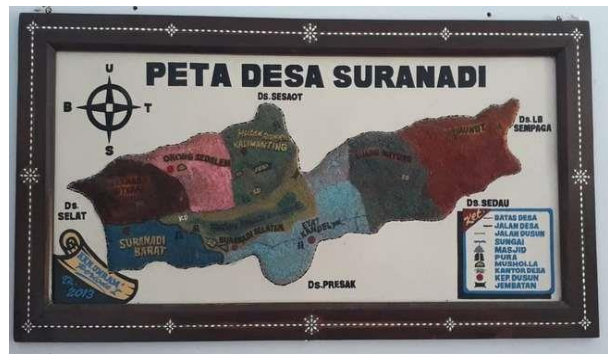

Gambar 1. Peta Lokasi Kegiatan Pelatihan Di Suranadi [Sumber: Arsip Desa Suranadi 2019]

Desa Suranadi adalah salah satu desa dari 21 desa yang ada di Kecamatan Narmada yang berdiri sejak tahun 1998. Pada awal terbentuknya desa Suranadi terdiri dari 5 Dusun, yaitu Dusun Suranadi Utara, Dusun Suranadi Selatan, Dusun Kalimanting, Dusun Eyat Kandel, dan Dusun Pemunut. Pada tahun 2007 Desa Suranadi memekarkan dusun-dusunya sehingga sejak tahun tersebut, desa ini terdiri dari 8 dusun yaitu: Dusun Suranadi Utara, Dusun Suranadi Selatan, Dusun Kalimanting, Dusun Eyat kandel, Dusun Pemunut, Dusun Suranadi Barat, Dusun Orong Sedalem, dan Dusun Kuang Mayung.

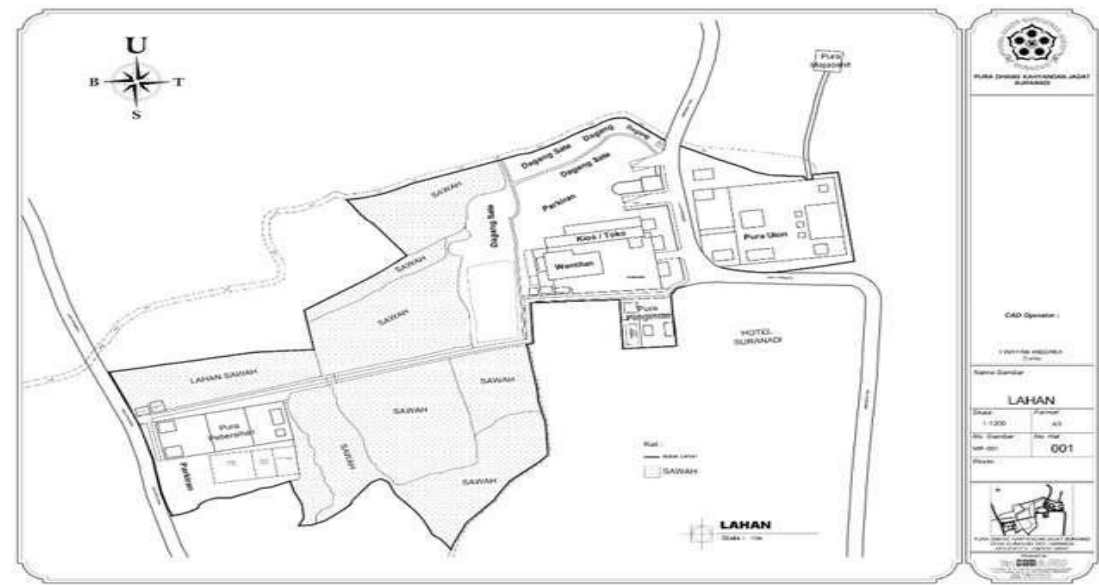

Gambar 2. Peta Lokasi Pura Suranadi

[Sumber: Dokumentasi Asip Desa 2021] 


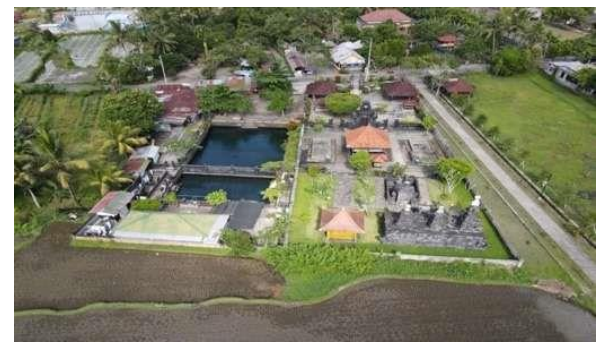

Gambar 3. Foto Lokasi kegiatan Pura Pembersihan Suranadi

[Sumber: Dokumentasi Putra Kariana 2020]

Pura yang berjarak 30 menit dari Kota Mataram ini merupakan bagian dari kawasan hutan wisata di Lombok barat. Suasana yang tenang memberikan kesan luar biasa kepada para pengunjung. Pura Suranadi memiliki sumber mata air yang disucikan umat Hindu. Seruputan air dari sumber mata air tersebut memberikan spirit rohani bagi para pengunjung Pura Suranadi. Pura ini memiliki pola pura yang terpisah satu sama lain yakni disesuaikan dengan keberadaan sumber mata air suci yang terdapat di lokasi tersebut. Walaupun terpisah secara fisik, namun dipandang sebagai satu kesatuan secara niskala ketika menjalankan rangkaian kegiatan ritual keagamaan. Keberadaan Pura Suranadi erat kaitannya dengan lima mata air (Panca Tirta) yang ada di lokasi tersebut, yaitu Mata Air Toya Tabah, Mata Air Toya Pabersihan, Mata Air Toya Panglukatan, Mata Air Tirta, dan Mata Air Pangentas.

Pura Suranadi terdiri dari tiga buah kelompok pura. Masing-masing diberi nama sesuai dengan fungsi sumber air yang ada di dalamnya. Tiap pura memiliki area jaba sisi, jaba tengah, dan jeroan (tri mandala). Pura-pura tersebut, antara lain (1) Pura Ulon, yakni terletak di ujung timur laut, berbatasan langsung dengan kawasan hutan lindung Taman Wisata Alam, halaman Pura Ulon terdapat Mata Air Panglukatan dan Petirtaan; (2) Pura Pangentas, terletak tidak jauh dari Pura Ulon ke arah barat daya. Pura ini dilengkapi dengan dua palinggih dan terdapat Mata Air Pangentas dan toya tabah. Pura ini difungsikan sebagai tempat mengambil air untuk upacara pitra yadnya; dan (3) Pura Pabersihan yang berlokasi sekitar 300 meter dari Pura Ulon. Pura ini memiliki Mata Air Pabersihan dengan beberapa macam palinggih dan bangunan pelengkap upacara.

Desa Suranadi merupakan salah satu Desa yang menjadi destinasi wisata dan desa swakarsa, bila dilihat dari kondisi mata pencaharian masyarakat yaitu di bidang perkebunan, pertanian dan pariwisata. Di bidang perkebunan, masyarakat memiliki perkebunan rambutan, durian, manggis. Di bidang pertanian, selain masyarakat mengembangkan lahan pertanian produktif, tidak sedikit juga masyarakat berusaha dalam pengembangan pertanian tanaman hias yang saat ini sedang berkembang di kalangan pencinta tanaman hias. Sementara di sektor pariwisata, masyarakat menyiapkan banyak pilihan kunjungan serta sarana yang digunakan bagi masyarakat atau pelaku yang berwisata religi seperti canang, daksina, banten dan lain sebagainya.

\subsection{Analisis Hasil Kegiatan}

Pelaksaaan kegiatan berproses dengan lancar sesuai jadwal yang ditetapkan, seluruh peserta hadir, dan durasi pelatihan selama dua jam sesuai waktu yang dijadwalkan. Dengan jumlah peserta yang terbatas memudahkan kegiatan pelatihan dan memaksimalkan interaksi antara instruktur dengan peserta. Penyampaian materi dipahami dengan baik sehingga respon peserta sangat bagus serta kegiatan praktek dilakukan secara maksimal. Peserta yang kebetulan tinggal di sekitar pura dan sebagai penjual canang sangat antusias menyimak pelatihan karena harapan mereka dapat mempraktekkan sesuai tujuan pelatihan dalam upaya memenuhi pelanggan yang ingin 
melaksanakan wisata spiritual. Antusias peserta pelatihan diharapkan dapat berkontribusi untuk kemajuan desa wisata Pura Suranadi. Pelaksanan pelatihan ini juga bertujuan meningkatkan keterampilan peserta dan efesiensi kerja. Sistematika pelatihan mengutamakan gaya, kreasi para peserta dalam metetuasan sehingga peserta merasa senang, percaya diri dan merasa berperan pada kelompoknya masing-masing. Menurut Keller (2010) dinyatakan pribadi yang merasa berperan dalam suatu kegiatan akan memunculkan confidence (percaya diri) sehingga merasa diri memiliki potensi untuk berinteraksi secara positif dengan lingkungan.

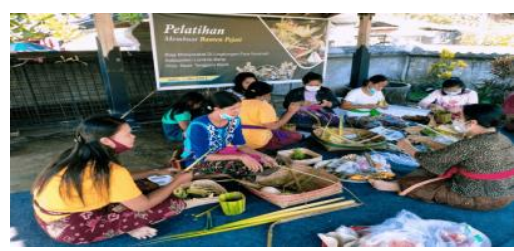

Gambar 4. Instruktur Mendemonstrasikan Pembuatan Banten Pejati Di Pura Suranadi [Sumber: Dokumen Pribadi (2021)]

Pelaksanaan pelatihan dilakukan secara berkelompok dengan jumlah peserta sembilan orang dan dibagi menjadi tiga kelompok yang terdiri masing-masing 3 orang. Setiap peserta mendapatkan kesempatan untuk melakukan praktek secara langsung.

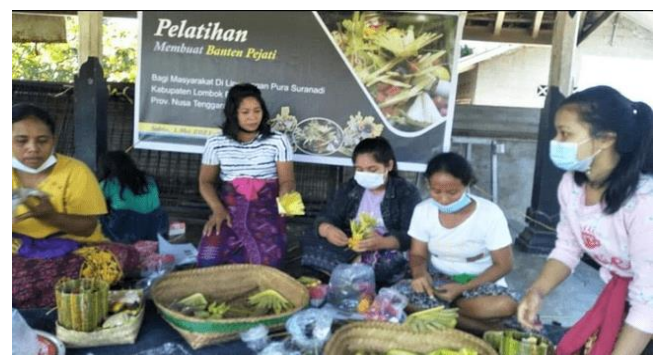

Gambar 5. Praktek Berkelompok Dalam Pelatihan Banten Pejati [Sumber: Dok. Pribadi (01 Mei 2021)]

Seluruh rangkaian kegiatan pelatihan para peserta yang bukan berprofesi sebagai penjual canang diharapkan dapat meringankan beban berupacara yang selama ini dilakukan secara besar-besaran tanpa mengindahkan esensi dari berupacara.

\subsection{Evaluasi Kegiatan}

Kegiatan pelatihan membuat banten pejati dilaksanakan dalam 2 tahapan yaitu: Evaluasi terhadap masing-masing peserta untuk mengetahui pemahaman peserta terhadap filosofi pembuatan upakara yadnya. Evaluasi dilakukan meliputi, kecekatan menginventarisir bahan-bahan, keterampilan mejejahitan, kemampuan menata banten (metanding) dan kebersihan. Penilaian dilakukan diawal kegiatan, proses, dan akhir. Observasi dilakukan oleh instruktur dan didampingi 3 orang narasumber baik secara individu dan kelompok. Obeservasi dilakukan menggunakan form evaluasi dan dilakukan dengan membuat catatan-catatan mulai dari persiapan, proses, dan pengerjaan banten. Sedangkan hasil akhir dinilai dari karya yang dihasilkan dari masing-masing kelompok. Hasil penilaian dari instruktur dan 3 orang pendamping dinyatakan bahwa peserta pelatihan yang berasal dari 3 katagori kemampuan peserta dengan rincian sebagai berikut: 1) Katagori peserta srati banten dan dagang canang secara filosofi belum dapat memaparkan makna dan filososfi banten namun terampil dalam mempersiapkan peralatan, sangat mampu dalam metetuasan dan merangkai banten 
2) Katagori peserta ibu-ibu rumah tangga dan pengurus desa adat memiliki sedikit kemampuan memahami filosofi banten mampu dalam mempersiapkan bahan, metetuasan dan metanding dengan benar

3) Katagori peserta dari genersi muda dan pelajar/mahasiswa mampu memahami filosofi karena sering membaca dan melihat referensi melalui media sosial, namun belum trampil dalam mempraktekkan pembuatan banten.

Kesimpulan hasil penilaian akhir peserta dengan tiga katagori peserta yang telah dilatih mulai dari pengenalan filosofi yadnya sampai penilaian akhir dinyatakan bahwa peserta memiliki minat belajar dan komampuan dalam pembuatan banten pejati. Pembagian kelompok yang dikombinasi antara ketiga katagori peserta mendapatkan hasil yang maksimal, karena dalam proses pembuatannya mereka berkolaborasi dan saling mengisi kekurangan masing-masing. Animo peserta sangat antusias dalam mengikuti pelatihan dibuktikan dengan kenginan peserta untuk diadakan pelatihan lebih lanjut untuk pelatihan sejenis.

\section{KESIMPULAN}

Pelatihan pembuatan banten pejati ini bertujuan untuk meningkatkan potensi ekonomi yang ada. Bahan-bahan yang digunakan dalam pembuatan banten ini tersedia cukup banyak di Desa Suranadi, sehingga dapat dengan mudah dan waktu yang relatif lebih cepat untuk memperolehnya. Artinya sebagian masyarakat akan ikut berperan secara tidak langsung maupun secara langsung dalam pengembangan ekonominya. Masyarakat akan berinteraksi dengan masing-masing anggotanya di lingkungan yang saling mendukung dan membutuhkan, serta memberikan manfaat yang sangat besar bagi bangsa dan Negara. Dengan demikian baik secara langsung maupun tidak langsung perekonomian daerah akan menjadi semakin berkembang, masyarakat memperoleh keterampilan yang dapat memberikan penghasilan tambahan atau bahkan penghasilan utama bagi mereka. Keberadaan pura bukan hanya sebagai tempat untuk memenuhi kebutuhan spiritual dan religius saja, tetapi juga mampu memberikan manfaat secara ekonomi bagi masyarakat di sekitarnya tanpa mengurangi esensi dan kesucian pura tersebut.

\section{DAFTAR PUSTAKA}

BKSDA Provinsi NTB. (2015). Taman Wisata Alam Suranadi, Narmada Kabupaten Lombok Barat (https//bksdantb.org/42/04/taman-wisata-alam-suranadinarmada-kabupaten lombok-barat/, diakses 15 Juli 2017)

Pratama, D. (2019). Gerakan Desa Sadar Wisata. Al-Quwwah: Jurnal Pengabdian Masyarakat, 3 (1).

Keller, M. (2010), Motivational Design For Learning And Performance The ARCS Model Approach, Springer.

Mantra, I. B. 2018. Bhagavadgita Alih Bahasa \& Penjelasan. Denpasar : ESBE Buku

Suardana, W. (2013). Analisis Kebijakan Pengembangan Pariwisata (Intervensi Melalui Kebijakan Pariwisata Berkelanjutan di Bali), Seminar Nasional Pariwisata Berkelanjutan, Program S3 Pariwisata Universitas Udayana

Sudarsana, I. B. (2010). Himpunan Tetandingan Upakara Yadnya. Yayasan Dharma Acarya Denpasar : Percetakan Bali

Suprastayasa, I. G. N. A., Adi, I. A. S. P., \& Iswarini, N. K. (2020). Pelatihan Merangkai Bunga Bagi Masyarakat Desa Wisata Gunung Salak, Tabanan, Bali. Jurnal Pemberdayaan Pariwisata, 2 (2). 
Sukmadewi, R., Darma P., \& Suardana. (2019). Potensi Dan Pengembangan Desa Wisata Suranadi Di Kecamatan Narmada Kabupaten Lombok Barat. Jurnal Master Pariwisata (JUMPA), 5 (2), 424-442. DOI: https://doi.org/10.24843/JUMPA.2018.v05.i02.p12 